\title{
WestVirginiaUniversity
}

THE RESEARCH REPOSITORY @ WVU

Graduate Theses, Dissertations, and Problem Reports

2001

\section{Factors affecting the accumulation of pentosidine in the skin of wild birds}

Richard Clair Chaney Jr.

West Virginia University

Follow this and additional works at: https://researchrepository.wvu.edu/etd

\section{Recommended Citation}

Chaney, Richard Clair Jr., "Factors affecting the accumulation of pentosidine in the skin of wild birds" (2001). Graduate Theses, Dissertations, and Problem Reports. 1299.

https://researchrepository.wvu.edu/etd/1299

This Thesis is protected by copyright and/or related rights. It has been brought to you by the The Research Repository @ WVU with permission from the rights-holder(s). You are free to use this Thesis in any way that is permitted by the copyright and related rights legislation that applies to your use. For other uses you must obtain permission from the rights-holder(s) directly, unless additional rights are indicated by a Creative Commons license in the record and/ or on the work itself. This Thesis has been accepted for inclusion in WVU Graduate Theses, Dissertations, and Problem Reports collection by an authorized administrator of The Research Repository @ WVU. For more information, please contact researchrepository@mail.wvu.edu. 
Factors Affecting the Accumulation of Pentosidine In the Skin of Wild Birds

\author{
Richard C. Chaney Jr.
}

Thesis submitted to the College of Agriculture, Forestry and Consumer Sciences at West Virginia University

In partial fulfillment of the requirement for the degree of

Master of Science

In

Animal and Veterinary Sciences

H. Klandorf, Chair

K. P. Blemings

D. Porter

Morgantown, West Virginia

2001

Keyword: Pentosidine, Aging, Birds, Skin, Collagen

Copyright 2001, Richard C. Chaney Jr. 


\section{ABSTRACT \\ Factors Affecting the Accumulation of Pentosidine In the Skin of Wild Birds \\ Richard C. Chaney Jr.}

Birds have few reliable indicators of aging. Pentosidine (Ps), a biomarker of aging, is a product of non-enzymatic glycation, which accumulates in the tissues of an animal over its lifespan. The intent of this study was to determine if comparable change in Ps concentrations could be established in the skin of wild birds of known ages. Skin samples were obtained from the breast of 44 birds of various species. Foot webbing samples were obtained from 24 California Gulls. Collagen was measured by a hydroxyproline spectrophotometric method and Ps was quantified using reverse phase HPLC. Ps concentration in the skin and foot webbing increased linearly with age $(\mathrm{p}<0.001)$. Measurement of Ps in birds of unknown ages provided age estimates within the established life-span of these species. Hydroxyproline concentrations from the foot webbing were comparable to that measured in the skin, however Ps concentrations were approximately one-fourth of that in skin. Knowledge regarding the longevity of birds could provide information for species survival programs (SSPs) and insight into variations in longevity of an entire population 


\section{Dedication}

This project is dedicated to my mother, Helene M. Weinberger

Who by her unwavering and unconditional support and love has allowed me to achieve a positive existence 


\section{$\underline{\text { Acknowledgements }}$}

I would like to express my sincere appreciation to my graduate advisor, Dr. Hillar Klandorf, for giving me this opportunity so late in life and for his constant positive encouragement, helpful counsel, and timely assistance throughout the course of this study.

The utmost gratitude is also extended to Dr. Kenneth P. Blemings who made an invaluable contribution to this project with his omnipotent technical advise. Special thanks is due to Dr. Dale Porter whose useful inputs and criticism led to the improvement of this research project.

I acknowledge the valuable contribution of Mr. Nabil Al-Humadi (NIOSH), in familiarization with the general techniques of the HPLC procedure. I also acknowledge the generous help of Diana Keller and Elizabeth Falkenstein in the early and latter stages of this project, respectively.

I wish to acknowledge the National Aviary in Pittsburg and its curator Jim Bonner for their constant enthusiasm and cooperation with obtaining samples and for the use of their facility.

I am grateful to West Virginia University for awarding me the graduate research assistantship, which is duly acknowledged.

I would also like to extend my appreciation to my fellow graduate students for making time in the laboratory enjoyable. 


\section{Table of Contents}

TITLE PAGE

ABSTRACT

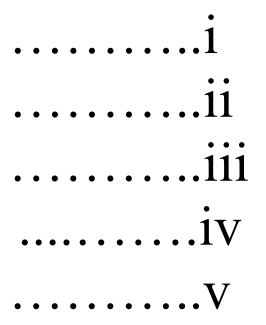

SECTION 1

Introduction

Objective

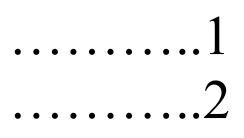

\section{SECTION 2}

Review of literature

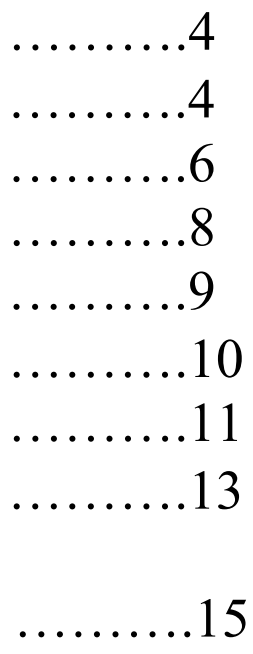

- Aging and birds

The role of free radicals in aging

The Maillard reaction

Advanced glycation end-products

- Pentosidine as a biomarker for aging

Collagen crosslinking

- Aging in Birds Vs. Mammals

Birds as an animal model

for the study of aging

\section{SECTION 3}

Pentosidine as a measurement of chronological age in wild birds 
1. Introduction

2. Materials and Methods

.........21

Sample collection and preparation

.22

Hydroxyproline measurement

.23

HPLC methods and pentosidine measurement ........23

Optimization of HPLC technique

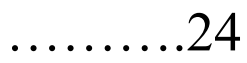

Statistical analysis

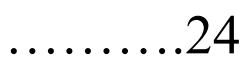

3. Results

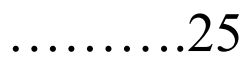

4. Discussion

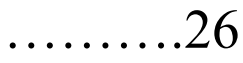

5. References

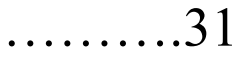

6. Tables and figures

.........34

\section{SECTION 4}

Bibliography

52 
Birds exhibit few outward signs of aging. Scientists have struggled with the inability to find reliable methods to predict unknown ages of wild birds. Graying of the muzzle, wear of teeth, wrinkling and coloration of the skin and strength of bones can be used to estimate a mammals age. However, sexually mature birds do not show obvious bodily changes with age.

Bird evolution produced anatomical differences that contribute to the problem of reliable aging. As flight developed, bones became hollow to reduce weight. The original bony jaw and teeth gave way to develop a hornlike beak. Feathers covered the skin to assist in better flight and aid in thermoregulation. The development of these characteristics complicates the ability to quantify aging in birds.

Presently, there are a number of ways to determine the difference between a juvenile and an adult bird. Wildlife biologists, ornithologists and researchers can mark changes in plumage, length of tail-feathers, and spur length (depending on species) to determine adulthood. More invasive measures include checking the bursa a fabricus to determine whether the 
bird has reached sexual maturity. While these outward signs provide a fairly reliable method by which to determine adulthood, they do not mark changes past adulthood.

Pentosidine is a protein crosslink that is formed through the nonenzymatic glycation of lysine and arginine residues. Pentosidine is a fluorescent, imidazo pyridinium compound (Sell and Monnier, 1989). Diabetes researchers have utilized biomarkers such as pentosidine to indicate the amount of cross-linked collagen within various tissues. Animals previously studied include rabbits, poultry, rats, and humans (Bellmunt, 1995; Iqbal 1999, Polharna, 1995; Reiser, 1995; Sell,1992).

Pentosidine accumulates exponentially in the collagen of mammals (Sell and Monnier, 1989, Sell et al., 1992). Iqbal confirmed that pentosidine is present in the skin of broiler breeder hens and that, in the hens, as in mammals, its concentrations increase with age (Iqbal et al., 1997,1999).

\section{OBJECTIVE}

The Primary objective of this study was to develop an index by which to age birds based on the quantity of pentosidine present in the skin of birds of known ages. This index would provide a convenient method of avian age estimation. 
If this aging technique could be applied to living birds, potential applications span various fields. In the case of endangered species, attempts are made to pair the most genetically compatible birds together to ensure best fit offspring. Because many birds mate for life, it is important to mate birds as completely as possible to insure total compatibility. The ability to estimate age in wild birds would eliminate many of the problems associated with pairing of endangered species. In addition, many birds used for research are still wild-caught. The ability to estimate age in these birds will contribute to more accurate data concerning population fluxes, behavioral patterns, and life cycles. Zoo programs (small population management) would also benefit from this technique in the areas of mating, behavioral patterns, and species specific physiology. Medical advances are being made in the study of age-linked diseases in birds. For example, hyperkeratinosis and hemochromotosis have been observed in domestic birds and are known to advance progressively with age. Knowledge of these diseases could aid in understanding of other late-life diseases such as diabetes. Techniques which quantify the accumulation of advanced glycation end-products have unforeseen benefits in other areas of aging research . 


\section{Literature review}

\section{Aging and birds}

Aging is a time dependent biological process common to all multicellular organisms. Aging is associated with a progressive decline in the efficiency of various physiological functions (Sohal and Weindruch, 1996). Aging is defined when two criteria are met: 1) the probability of death at any point in time increases with the age of the organism and 2) characteristic changes in phenotype occur in all individuals over time due to the limiting processes (Johnson et al., 1999). The phenotypic definition is important in distinguishing the aging process itself from diseases of aging. Phenotypes of aging affect all of the individuals in a population, while diseases of aging affect only a subset. There are a variety of strategies, models and hypothesis that have been used to understand the deleterious processes of aging. The consensus among researchers views the concept of aging as a living organism's failure to maintain homeostasis (Holliday, 1992). Aging theories can be distributed into two broad categories based on putative casual forces: 1) intrinsic factors referring to genomic components and genetic processes; and 2) extrinsic factors, encompassing various external influences on the 
organism ( Iqbal, 1999). Weindruch and co-workers (2001) proposed 5 nonexclusive explanations for the aging process:

1) Damage from oxidative stress ( see Sohal et al., 1996)

2) Damage from glycation reactions (see Kristal and $\mathrm{Yu}$ 1992)

3) Increases in body temperature associated with a hypermetabolic state (see Walford and Spindler 1997)

4) Alterations in gene and protein expression (see Van Remmen et al., 1995)

5) Neuroendocrine changes (see Nelson et al., 1995)

Weindruch and colleages used microarray technology to survey 6,347 genes from gastrocnemius muscle cells of male mice subjected to caloric restriction. Caloric restriction has been studied extensively as a method to retard the aging process. When compared to the control group, mice subjected to caloric restriction exhibited altered gene expression in $84 \%(26 / 31$ genes $)$ of the four major gene classes that displayed ageassociated alterations (stress, biosynthesis, protein metabolism and energy metabolism) in normal aged mice. Weindruch and co-workers concluded that aging is characterized by an adaptive response consistent with increased production of reactive oxygen species. The Weindruch study proposed that activation of neuronal and myogenic responses to injury were secondary. 
In comparison to their mammalian counterparts, birds, in a physiologic sense, age much more slowly. However, among various avian orders there is broad variation in aging rates and patterns. Poultry species (order Galliforms), including domestic chickens, turkeys, cortunix quail, and most common laboratory animals, are the shortest-lived and most rapidly aging birds. Alternatively, parrots (order Psittaciformes), seabirds (Charadriiformes), songbirds (Passeriformes), hummingbirds (Apodiformes), and raptors (Falconiformes) all include representatives with exceptionally long life spans and retarded aging rates for their body size. The comparative longevity and slow aging of birds relative to mammals is documented with data from captive zoo populations and pet birds as well as maximum life-span data from mark-recapture studies of wild birds in nature (Lindstedt and Calder, 1976; Finch, 1990; Holmes and Austed; 1995 Ricklefs, 1998).

\section{The role of free radicals in aging}

Relatively higher metabolic rates $\left(\mathrm{Rat}=750 \mathrm{ul} \mathrm{O}_{2} / \mathrm{g} / \mathrm{hr}\right.$., Pigeon $=1500 \mathrm{ul}$ $\mathrm{O}_{2} / \mathrm{g} / \mathrm{hr}$.) require birds to consume more oxygen per gram tissue than mammals of comparable body size (Barja et al., 1994). Damaging reactive 
oxygen species (ROS), a by-product of normal metabolism, contribute significantly to the accumulated cellular damage associated with aging.

Holmes et al., (2001) proposed two different mechanisms that could explain how birds minimize oxidative damage that contributes to cellular decline.

1) Birds may produce fewer ROS per mole of oxygen consumed, the result of more efficient mitochondrial electron transfer.

2) Birds may possess increased relative antioxidant activity that provides resistance to damage from ROS.

Two independent studies found $\mathrm{H}_{2} \mathrm{O}_{2}$ accumulation in tissues of pigeons (Colombia livia) was only about one-tenth of that in Norway rats (Rattus norvegicus) (Ku and Sohal, 1993; Barja et al., 1994) However, the relative activity of antioxidant enzymes in the two studies was not in agreement. Ku and Sohal (1993) reported an increase in the relative activity of antioxidant enzymes in the pigeon when compared to the rat, whereas Barja and co-workers (1994) found a general decrease in the antioxidant enzyme (Superoxide dismutase, Catalase, Seleniumdependent GSH-peroxidase, GSH-reductase, and Ascorbate) activity of pigeons compared to rats. Herrero and Barja (1988) also found lower 
antioxidant enzyme activity in adult male parakeets (Melopsittacus undulatus) and canaries (Serinus canarius) when compared to rats.

Ogburn and colleagues (1998) determined that avian cells have a greater resistance to oxidative challenge when cultured kidney epithelial cells were exposed to various pro-oxidants $\left(95 \%\right.$ oxygen, $\mathrm{H}_{2} \mathrm{O}_{2}$, and paraquat). The results of the Ogburn study showed that cells from three long-lived bird species survived longer and suffered less DNA damage than did mouse cells.

The defenses that birds possess with regard to oxidative stress could be structural and constituitive (decreased ROS production per mole of oxygen) or inducible (increased relative antioxidant activity) but more likely are a combination of both.

\section{The Maillard reaction}

The Maillard reaction is the non-enzymatic attachment of reducing sugars with amino groups on protein. The reaction is initiated when an aldehyde group $(\mathrm{CHO})$ of glucose and an amino group $\left(\mathrm{NH}_{2}\right)$ of protein combine. This formation is termed a Schiff base and is very unstable. The Schiff base quickly rearranges itself into a more stable substance known as an Amadori product (Cerami et al., 1987). These Amadori products slowly dehydrate and rearrange themselves into irreversible structures termed advanced 
glycation end products (AGE's). Many AGE's are able to cross-link with adjacent proteins. Maillard reactions have been targeted as a key player in age-related diseases and diabetic pathological conditions (Cerami, 1985).

\section{Advanced glycation end-products}

Advanced glycation end-products have been used as biomarkers of aging in tissues of humans and laboratory animals. AGE's are thought to cause the age-dependent yellowing and crosslinking in long lived proteins such as lens crystallins and collagen. Cellular receptors recognize AGE's and can initiate cellular events that induce tissue damage associated with aging. Kristal and $\mathrm{Yu}$ (1992) developed the synergistic theory of aging based on the observation that AGE's require successive oxidative steps which may be associated with free radical damage. The structures of AGE's that have been elucidated include carboxymethllysine (CML), pentosidine (Ps), and arginine-lysine imidizole (ALI) (Wells-Knecht et al.,1996, See Fig 1). Chellan and Nagaraj (1999) established the first HPLC technique to quantify the dicarbonyl derived imidazoliam crosslinks methylglyoxal-lysine-dimer (MOLD) and glyoxal-lysine-dimer (GOLD). GOLD and MOLD are neither chromophores nor flourophores which prompted Chellan and Nagaraj to use their phenylisothiocyanate (PITC) derivatives for UV detection. AGE's have 
now been measured in a small number of bird species including glycated hemoglobin studies in the long-lived avian order Apodiformes (hummingbirds) (Beuchat and Chong, 1998) as well as pentosidine concentration in skin collagen in the short-lived order Galliformes (domestic chickens) ( Iqbal et al., 1999, Klandorf et al., 1999)

\section{Pentosidine as a biomarker for aging}

Pentosidine is a widely documented Maillard structure first islolated by Sell and Monnier (1989a) and described as an imidazopyridinium compound (Sell and Monnier, 1989b) comprised of single lysine and arginine moieties crosslinked by a pentose. It was identified as the product of the Maillard reaction elicited by hexoses, pentoses, ascorbate and a variety of Amadori compounds in vitro (Sell and Monnier 1989a, 1989b; Dyer et al., 1991; Grandhee and Monnier, 1991). However, the major in vivo carbohydrate source leading to the formation of pentosidine is not known.

Oxidation reactions are required at some stage of the reaction as pentosidine formation is inhibited in the absence of oxygen. Baynes (1991) introduced the phrase 'glycoxidation product' to describe pentosidine and other glycation compounds similarly affected by the availability of oxygen. Pentosidine has been found to increase exponentially in the collagen of 
mammals over the animal's lifespan (Sell and Monnier, 1989, Sell et al., 1992). Iqbal confirmed that pentosidine is present in the skin of broiler breeder hens and that, in the hens, as in mammals, it accumulates with age (Iqbal et al., 1997,1999). Diabetes researchers have utilized biomarkers such as pentosidine to indicate the amount of cross-linked collagen within various human tissues. The measurement of pentosidine in the tissues of animals is greatly facilitated by its acid stability and its flourescent properties. However, Dyer et al., (1991) presented evidence that pentosidine represents less than $1 \%$ of the total crosslinks formed during the in vitro Maillard reaction of proteins with glucose. Fast atom bombardment high resolution mass spectrometry showed a mass/charge of 379, 2069 compatible with the empirical formula $\mathrm{C}_{12} \mathrm{H}_{27} \mathrm{~N}_{6} \mathrm{O}_{4}$.

\section{Collagen crosslinking}

Collagen is a ubiquitous tissue protein that constitutes approximately $30 \%$ of the protein in mammals. Collagen has been identified in 19 different forms and has a variety of biological functions (McCormick, 1999).

The physical properties of collagen change as a result of cross-linking and contribute to the stiffness in skin, tendon, joints, and overall tissue rigidity. The accumulation of AGE's is associated with alterations in 
mechanical properties, solubility, ligand binding and conformation of collagen (Reiser, 1991). Collagen can be separated by type and location. Type I, II, and III collagen are the most abundant types with type I collagen accounting for $90 \%$ of total body collagen. Type I,II, and III collagen are long fibrous rod-like molecules. Type I collagen forms the connective tissue of skin, bone, tendon, ligaments, dentine, sclera, fascia, and organ capsules. Type II collagen is a major component of cartilage, notochord, and the intervertebral disk. Type III collagen is associated with the connective tissue of organs (uterus, liver, spleen, kidney, lung, etc.) smooth muscle, endoneurium, blood vessels, and fetal skin (Ross et al., 1995). Collagen crosslinks can be classified into two major areas:

1.) Crosslinks that are important during normal development and maturation and are controlled by the enzyme lysyl oxidase (Siegel 1979; Reiser et al., 1992)

2.) Crosslinks that are derived from the non-enzymatic addition of carbohydrate moieties and contribute to accelerated tissue aging ( Cerami 1985; Baynes and Monnier, 1989; Reiser, 1991) 
Recent theories suggest that non-enzymatic glycosylation of tissue proteins in combination with other processes such as free radical generation contribute significantly to the aging process ( Masoro et al., 1989; Kristal and $\mathrm{Yu}, 1992$; Weindruch et al., 2001). Verzigl and colleagues (2000) calculated the half-life of human cartilage collagen to be 117 years and that of skin collagen to be 15 years. Collagen molecules provide a reliable method by which to quantify pentosidine crosslinks and other AGE's due to their exceptionally long half-life.

\section{Aging in Birds Vs. Mammals}

Birds are remarkably longer-lived than mammals of comparable body size. Maximum longevity of wild birds average 1.7 times greater than captive mammals, and captive birds are nearly three times as long -lived as captive mammals (Lindstedt and Calder, 1976; Austed and Fischer, 1991). Scarlet Macaws (Ara macao) have documented captive life spans to over 90 years. This is more than four times longer than would be predicted for a mammal of equivalent body size. Common Ravens, (Corvus corax), have lived in captivity up to 69 years. Hummingbirds are the most disproportionately long-lived birds. Hummingbirds are the smallest bird species with the highest metabolic rate (Holmes and Austed, 1995). The Planalto Hermit, 
(Phaethirnis pretrei), a hummingbird with an average weight of 15 grams, has a recorded captive lifespan of 14 years. The shortest lived and most rapidly producing and senescing bird species of any size documented to date is the Common Quail, Coturnix, with a mean life span of one year in the wild (Holmes and Austed, 1985). However, this 90g bird ages much more slowly than an equivalent sized rodent.

A deeply rooted theory of aging suggests that an organism's longevity is inversely related to its metabolic rate (Comfort, 1979; Holliday, 1992). The validity of the metabolic rate hypothesis has been challenged due to recent studies with caloric restricted (CR) animals. Caloric restriction has long been known to extend the life span of rodents (Weindruch and Walford, 1982, 1988). However, Masoro and co-workers (1991) found that caloric restricted rats have metabolic rates similar to their non-restricted counterparts, yet have much longer lifespans. Holmes and Austed (1995) called for a reassessment of metabolic rate as the major determinant in the aging process based on substantial evidence from comparative studies of various species of birds. The results from these collective studies find that birds and bats have substantially longer life spans than would be predicted based on their metabolic rate (Holmes and Austed, 1995; Barja et al., 1994). Consideration must also be given to how selection pressure will effect aging. 
Namely, other things being equal, species subject to low levels of extrinsic mortality can age more slowly than species subject to high mortality rates. This theory of aging predicts that most birds should age more slowly than mammals because flight affords protection against extrinsic mortality due to predation or accident (Edney and Gill, 1967; Austed and Fischer, 1991).

\section{Birds as animal models for aging}

The longevity of birds provides researchers with an interesting paradigm because birds exhibit several traits which current theories of aging suggest should render them more susceptible the degenerative processes of aging. Birds have metabolic rates as much as 2.0-2.5 times higher than those of similar sized mammals (Lindstedt and Caulde, 1976); concentrations of plasma glucose typically 2.0-6.0 times higher than those of mammals, and a body temperature approximately $3^{\circ}$ Celsius higher (Holmes and Austad, 1995). Modern theories of aging consider an increase in any one of these parameters as contributors to accelerated tissue damage due to the accumulation of deleterious by-products of oxidative metabolism and the Maillard reaction (Cerami, 1985; Monnier et al., 1991; Kristal and Yu, 1992; Weindruch et al., 2001). Birds seem to have developed mechanisms to protect against free radical damage and advanced Maillard reactions, 
consequences of high metabolism, high body temperature, and elevated blood glucose. It has been proposed that birds have special mechanisms to prevent the formation of such products, degrade them once they are formed, remove affected cells, or some combination of the three to live longer (Holmes and Austed, 1995; Monnier, 1990; Iqbal et al., 1997). Class aves offers a unique perspective from which to study the proposed protective mechanisms that limit free radical production, Maillard reaction damage, AGEs formation, and may offer insight into medical intervention for retarding aging. 
Figure 1. Structure and pathways of formation for three advanced glycation end-products (AGEs). Formation of carboxymethyllysine (CML) and pentosidine involves oxidative steps while argininelysine imidizole (ALI) forms non-oxidatively. 


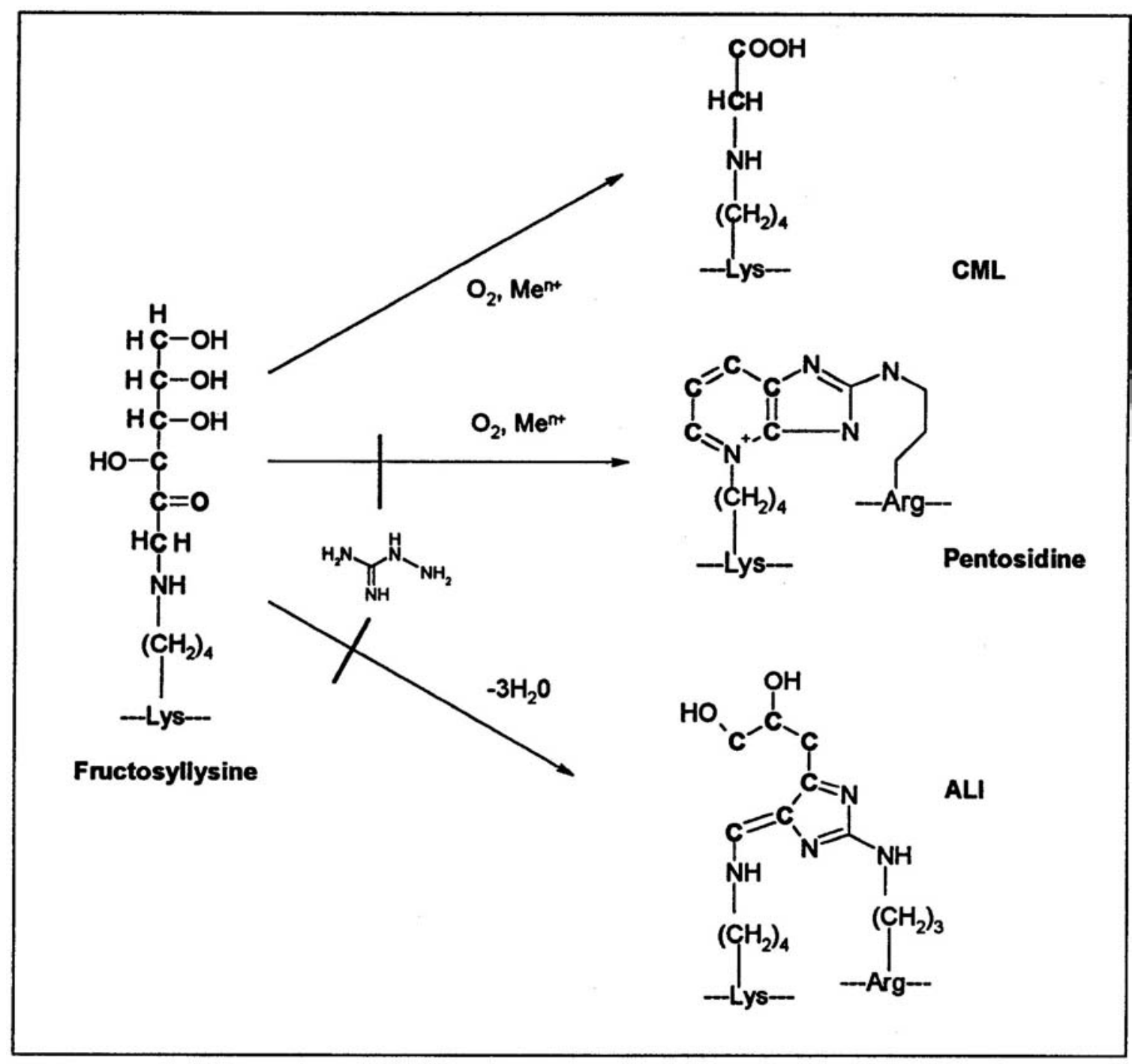




\section{Pentosidine as a measurement of chronological age in wild birds}

Richard C. Chaney Jr., Kenneth P. Blemings, James Bonner*, Hillar Klandorf

Division of Animal and Veterinary Sciences, University of West

Virginia, Morgantown, West Virginia 26506, USA

e-mail hklandor@wvu.edu

* National Aviary, Pittsburg, PA 16212 
In many species, visual clues can be used to help estimate age, from skin wrinkling in humans to graying or whitening of the muzzle and wear of teeth in many other mammalian species. However, in birds, evolution has produced anatomical differences that contribute to the problem of reliable aging. The original bony jaw and teeth gave way to development of a hornlike beak. Feathers covered the skin to assist in better flight and aid in thermoregulation. The development of these characteristics complicates the ability to quantify aging in birds.

Pentosidine is a product of non-enzymatic glycation (the attachment of a carbohydrate moiety to lysine and arginine residues without the aid of enzymes) and it has been described as a fluorescent, imidazo pyridinium compound (Sell and Monnier, 1989). Collagen pentosidine has been found to increase exponentially over a mammals lifespan. (Sell and Monnier, 1989, Sell et al., 1992). Iqbal confirmed that pentosidine is present in the skin of broiler breeder hens and that, in hens, as in mammals, its concentrations increase with age (Iqbal et al., 1997,1999). Diabetes researchers have utilized biomarkers such as pentosidine to measure cross-linked collagen 
within various tissues. Numerous studies with mammals and domestic poultry have validated the use of pentosidine as a biomarker for aging (Bellmunt, 1995; Iqbal 1999, Polharna, 1995; Reiser, 1995; Sell,1992).

We are using pentosidine to estimate the age of wild birds. Reliable estimation of a bird's age could play a critical role in Species Survival Plans (SSPs) and the pairing of endangered species. Many birds, especially passerines, are still wild-caught. If this technique could be applied to living birds, it will help us gain insight concerning life cycle and population fluxes (i.e. maximum and average life span, generational span, onset and length of reproductive life, etc).

By compiling pentosidine data from a variety of species and ages we were able estimate the ages of unknown birds. Additionally, continuing data collection will permit the correlation of pentosidine accumulation as a function of habitat, diet, and migratory status.

\section{Materials and Methods}

To determine the relationship between pentosidine accumulation and age we obtained approximately 20 grams of skin from the lateral sides of the abdomen and thorax of previously frozen birds. Samples were obtained in collaboration with James Bonner, Curator of Birds, National Aviary, 
Pittsburgh, PA. Samples were stored at -70 degrees C. The samples collected consisted of 46 birds of known ages and 5 birds of unknown ages spanning 32 different species. The ages of these birds varied from a few days to 18.5 years. A second study was conducted using foot webbing from California Gulls of known ages $(\mathrm{n}=17)$. The samples were obtained as part of a blind study in cooperation with Donna Holmes from the University of Idaho and Bruce Pugesek from the University of Washington. Footweb skin specimens were collected in July and August, 1997, from members (adults and chicks near fledging age) of a breeding colony of California gulls (Larus californicus) located on an island in Bamforth Lake, Adams County, Wyoming. Tissue samples were collected within $30 \mathrm{~min}$. from the time of death. Skin was excised (about 1.5 to $2 \mathrm{~cm}$ in area) from between the toes of each bird. Skin was immediately placed into sterile saline and quick-frozen on dry ice. Samples were subsequently stored at -70 degrees C. Specimens were coded so that ages and identities of birds were unknown to our lab during the pentosidine quantification procedure. The samples of foot webbing and breast skin were prepared and quantified similarly.

The skin was prepared according to the techniques described by Monnier et al., (1986), Sell et al., (1992), and Iqbal et al., (1997). Briefly, this technique involved the removal of the epidermal and adipose layers 
from the skin, homogenization, and extraction with 2:1 chloroform methanol. Further preparation of the digest for the pentosidine assay involves digestion with $6 \mathrm{~N} \mathrm{HCl}$, purging with $\mathrm{N}_{2}$, heating for 18 hours at $110^{\circ} \mathrm{C}$, evaporating the acid in a centrifuge-type vacuum drier (Savant Instruments, Farmingdale, NY), reconstituting in 500ul water and final filtration using a .45 micron Costar Spin-X centrifuge tube filter (Corning Costar Corp., Cambridge, MA) A modified Stegman and Stadler spectrophotometric method for hydroxyproline was used for estimation of collagen in the reconstituted digest. The assumption was made that collagen was $14 \%$ hydroxyproline by weight (Maekawa et al. 1970). Pentosidine concentration was estimated using a reverse-phase HPLC procedure. Thirtyfive microliters of sample were injected into a Waters 2690 HPLC (Waters Corporation, Milford, Mass) with an on line scanning florescence detector (Waters 494, excitation $325 \mathrm{~nm}$, emission $370 \mathrm{~nm}$ ) used to monitor the pentosidine peaks. Duplicate samples were spiked with a known concentration of pentosidine to ensure quantification of the correct peak (see fig. 1). Separations were achieved by the application of a linear gradient of $5-28 \%$ acetonitrile from 0 to $35 \mathrm{~min}$ in water and $0.01 \mathrm{M}$ heptafluorobutyric acid at a flow rate of $1 \mathrm{ml} / \mathrm{min}$. Final quantification of pentosidine was made by comparing peak areas with a pentosidine standard (Vincent M. Monnier, 
Case Western University, Cleveland, $\mathrm{OH}$ ) curve obtained under similar conditions (see fig. 4). The software package Millennium 32 Version 3.05.01 was used for the integration of peaks.

\section{Optimization of HPLC method}

HPLC technique for quantification of bird skin pentosidine was modified from a method described by Iqbal and co-workers in 1999. The linear gradient of acetonitrile was reduced from $12-42 \%$ to $5-28 \%$. The gradient run was lengthened in time from 20 to 35 minutes. Sharper peaks were obtained using a C-18 column (YMC ODS-AQ 4.6 x 250mm ) with a 5um particle size. The column was cleaned for 18 minutes between each run and allowed to equilibrate for 12 minutes. Utilization of this technique provided greater separation from unknown peaks with minimal tailing and consistent retention times.

\section{Statistical Analyses}

Regression analysis was performed to determine the correlation between the concentration of pentosidine and chronological age. Data was analyzed using JMP statistical software (SAS Institute Inc., Cary, N.C.) A two-tailed t-test was performed to determine differences in the mean 
collagen content and the mean pentosidine concentration in breast skin and foot webbing.

\section{Results}

Pentosidine was found in the skin of various species of wild birds and its concentration increased linearly with age $(\mathrm{P}<0.001)$ (see fig. 2$)$. Linear regression analysis provided the best fit $\left(y=0.2047 x+7.4725, R^{2}=0.73\right)$ for breast skin pentosidine concentration as a function of age. Alternative regression analysis did not improve the correlation between breast skin pentosidine concentration and age. In addition, given the strong correlation between pentosidine accumulation and age, we have estimated the ages of birds with previously unknown ages (see Table 1). All age estimations are within the range of each species maximum life span. Pentosidine concentration accumulated in a linear fashion with age in foot webbing. $(\mathrm{P}<0.001)$ (see fig. 3). Linear regression analysis provided the best fit $\left(y=0.013 x+3.8467, R^{2}=0.70\right)$ for foot webbing pentosidine concentration as a function of age. Alternative regression analysis did not improve the correlation between foot webbing pentosidine concentrations and age. Different areas of the foot webbing from the same sample showed no difference in pentosidine concentration (see sample $\mathrm{A}=4.78 \mathrm{pmol} \mathrm{Ps} / \mathrm{mg}$ 
collagen vs. sample $\mathrm{AM}=4.95 \mathrm{pmol} \mathrm{Ps} / \mathrm{mg}$ collagen, $\mathrm{N}=1$, Table 3 ). The mean collagen content and mean pentosidine concentrations were calculated for breast skin and foot webbing. Samples from the breast skin were age selected to reflect the ages of the birds from which the foot webbing samples were obtained (48-288 months). The mean collagen content in breast skin $(5.73+3.04 \mathrm{mg} /$ collagen $/ 40 \mathrm{mg}$ tissue $)$ was not significantly different when compared to the mean collagen content of foot webbing (3.63+.963mg/collagen/40mg tissue). However, the mean pentosidine concentration in breast skin $(18.9 \pm 13.7 \mathrm{pmol} \mathrm{Ps} / \mathrm{mg}$ collagen $)$ was noticeably higher when compared to the mean pentosidine concentration in foot webbing (5.72 $\pm 1.88 \mathrm{pmol} \mathrm{Ps} / \mathrm{mg}$ collagen) although statistical analysis with a two-tailed t-test showed no difference between the means (see Table 2).

\section{Discussion}

Numerous species of birds, including parrots (order Psittaciformes), seabirds (Charadriiformes), songbirds (Passeriformes), hummingbirds (Apodiformes), and raptors (Falconiformes) live for unusually long periods of time when compared to mammals of comparable body size (Lindstedt and Calder, 1976; Finch, 1990; Holmes and Austed, 1995 Ricklefs, 1998). Poultry species (order Galliforms), including domestic chickens, turkeys, 
and cortunix quail, are the shortest-lived and most rapidly aging of bird species.

Advanced glycation endproducts (AGEs) have been measured in a small number of bird species including glycated hemoglobin studies using boronate affinity chromatography (Beuchat and Chong, 1998). Beuchat and Chong reported levels of glycohemoglobin to be lower in duck, chicken, and turkey (0.5-1.0 percent range) when compared to the average values for mammals (1.7-5.8 percent range). However, bird erythrocytes are less permeable to glucose than most mammalian red blood cells and also have half-lives of 50-70 percent of mammalian cells. Pentosidine concentration in skin collagen has been measured in the short-lived order Galliformes (domestic chickens) and its concentration shown to increase linearly with age ( Iqbal et al., 1999, Klandorf et al., 1999). Pentosidine detection in the tissues of animals is greatly facilitated by its acid stability and its flourescent properties. Collagen molecules provide a reliable method by which to quantify pentosidine crosslinks and other AGE's due to their exceptionally long half-life (117 years in cartilage collagen, 15 years in skin collagen) (Verzigl et al., 2000).

The idea to estimate chronological age of avian species via analysis of pentosidine concentration in skin is unique. The results of this study 
demonstrate that not only is pentosidine present in the skin of various species of wild birds, but that it can be used as a reliable estimator of chronological age. Pentosidine concentrations had greater variability as the ages of the birds increased. Differences in metabolism, diet, habitat, and sex could play a role in pentosidine accumulation from species to species.

However, a strong correlation between pentosidine accumulation and age still exists when these factors are not represented in the model. In order to determine the effect of metabolism, diet, habitat, and sex on pentosidine accumulation, further data collection will be necessary.

Potential nonexclusive explanations for the slightly lower concentration of pentosidine in the foot webbing include:

1) Low vascularization to the tissue, resulting inlimited flow of glucose residues necessary to form Amadori products, 2) lower tissue temperature retards the rate of the non-enzymatic reaction, 3) higher levels of uric acid in the extremities (due to lower temperatures) limit the generation of glycoxidation products. Uric acid is highly insoluble in plasma and readily precipitates at higher concentrations.

The strong correlation between pentosidine concentration and age in foot webbing indicate that a non-lethal technique using biopsy punches from the bird foot may be established. This procedure for age estimation will be of 
great benefit to wildlife biologists and researchers in the field of wildlife biology.

The longevity of birds provides researchers with an interesting paradigm because they exhibit several traits which current theories of aging suggest should render them more susceptible the degenerative processes of aging. Birds have metabolic rates as much as 2.0-2.5 times higher than those of similar sized mammals (Lindstedt and Caulde, 1976); concentrations of plasma glucose typically 2.0-6.0 times higher than those of mammals, and a body temperature approximately $3^{\circ}$ Celsius higher (Holmes and Austad, 1995). Modern theories of aging consider elevation of these parameters contributors to accelerated tissue damage from the accumulation of deleterious by-products of oxidative metabolism and the Maillard reaction ( Cerami, 1985; Monnier et al., 1991; Kristal and Yu, 1992; Weindruch et al., 2001). Birds seem to have developed mechanisms to protect against free radical damage and advanced Maillard reactions, consequences of high metabolism, high body temperature, and elevated blood glucose. It has been proposed that birds may have special mechanisms to prevent the formation of such products, degrade them once they are formed, remove affected cells, or some combination of the three to live longer (Holmes and Austed, 1995; Monnier, 1990; Iqbal et al., 1997). Class aves offers a unique perspective 
from which to study the proposed protective mechanisms that limit free radical production, Maillard reaction damage, AGEs formation, and may offer insight into medical intervention for retarding aging.

The ability to establish a technique for age estimation in wild birds will provide far-reaching benefits to aviculture, ornithology, and science in general. Such information could have a significant impact not only on the database of general avian knowledge, but also on the survival of the most critically endangered species. 


\section{References}

Bellmunt, M.J., Portero M., Pamplona, R., Cosso, L., Odetti P., and Prat J., 1995, Evidence for the Maillard reaction in rat lung collagen and its relationship with solubility and age. Biochimica et Biophysica Acta. 1272:53-60.

Beuchat, C.A., and Chong, C.R. 1998. Hyperglycemia and its consequences for hemoglobin glycation. Comp. Biochem. Physiol. A120:409-416.

Cerami, A. 1985. Hypothesis: Glucose as a mediator of aging. J. Am. Geriatr. Soc. 33:626-634.

Finch, C.E., 1990. Longevity, senescence, and the genome. University of Chicago Press.

Holmes, J. D., and Austad, S. N. 1995. Birds as animal models for the comparative Biology: prospectus. J. Geront: Biol. Sci. 50A:B59-B66.

Iqbal, M., Probert, L.L., and Klandorf, H. 1997. Effect of dietary aminoguanidine on tissue pentosidine and reproductive performance in broiler breeder hens. Poultry Sci. 76:1574-1579.

Iqbal, M., Probert, L.L., Al-humadi, N.H. and Klandorf, H. 1999. Protein glycosylation and advanced glycosylation endproducts (AGEs): An avian solution. J. Gerontol: Biol. Sci. 54: B1-B6

Iqbal, M., Kenney, P.B., Klandorf, H. 1999. Age-related changes in meat tenderness and tissue pentosidine: Effect of diet restriction and aminoguanidine in broiler breeder hens. Poultry Sci. 78:1328-1333.

Klandorf, H., Probert, L.L., and Iqbal, M. 1999. In the defense against hyperglycemia: An avian strategy. Worl.Poutry Sci. 55:1-17.

Kristal, B.A. and Yu, B. P. 1992. An emerging hypothesis: synergistic induction of aging by free radicals and Maillard reactions. J. Gerontol. Biol. Sci. 47:B107-114. 
Lindstedt, S. L., and Calde, W. A. 1976. Body size and longevity in birds. Condor 78,91-94.

Maekawa, T., Ratinasamy, K.I., Altman, Y.K., and Forbes., W.F. 1970. Changes in collagen with age-I. The extraction of acid soluble collagens from the skin of mice. Exp. Gerontol. 5:177-186.

Monnier, V.M., Vishwanath, V., Frank, K.E., Elmets, C.A., Dauchot, P., and Kohn, P.R. 1986. Relationship between complications of type I diabetes mellitus and collagen-linked fluorescence. N. Engl. J. Med. 314:403-408.

Monnier, V.M., 1990. Nonenzymatic glycosylation, the Maillard reaction and the aging process. J. Gerontol. Biol. Sci. 45:B105-B111.

Monnier, V.M., Sell, D.R., Nagaraj, RH. Mityata, S. 1991. Mechanisms of protection against damage mediated by the Maillard reaction in aging. Gerontology 37:152-165.

Polharna, H.K., Monnier, V.M., Boja, B., and Moskowitz R. W., 1995, Lysyl Oxidase and Maillard reaction-mediated crosslinks in aging and osteoarthritic rabbit cartilage. J. Orthopedic Res. 13:13-21.

Reiser, K.M. 1994. Influence of age and long-term dietary restriction on enzymatically mediated crosslinks and nonenzymatic glycation of collagen in mice. J. Gerontol: Biol. Sci. 49:B71-B79.

Reiser, K.M.,McGee C., Rucker R., and McDonald R., 1995. Effects of aging and caloric restriction on extracellular matrix biosynthesis in a model of injury repair in rats: J. Geron: Biol.Sci. 50A:B40-B47.

Ricklefs., R.E. 1998. Evolutionary theories of aging : conformation of a fundamental prediction, with implications for the genetic basis and evolution of life span. Amer. Nat. 152:22-24.

Sell, D.R., and Monnier, V.M., 1989. Isolation, purification, and partial characterization of novel flurophores from aging human insoluble collagenrich tissue. Conn. Tiss. Res. 19:77-92. 
Sell, D.R., and Monnier, V.M., 1989. Structure elucidation of a senescence cross-link from human extracellular matrix. Implication of pentoses in the aging process. J. Biol. Chem. 264:21597-21602.

Sell, D.R., Lapolla, A., Odetti, P., Fogarty, J., and Monnier, V.M. 1992. Pentosidine formation in skin correlates with severity of complications in individuals with long-standing IDDM. Diabetes, 41:1286-1291.

Verzijl., N., Degroot, J., Thorpe, S.R., Bank, R.A., Shaw J.N., Lyons, T.J., Bijlsma, J.W.J., Lafeber, F.P.J., Baynes, J.W., and TeKoppele, J.M. 2000. Effect of collagen turnover on the accumulation of advanced glycation end products. J. Biol. Chem. 275:39027-39031

Weindruch, R., Kayo, T., Lee, C., and Prolla T.A. 2001 Microarray profiling of gene expression in aging and its alterations by caloric restriction in mice. J. Nutr. 131:918S-926S. 
Figure 1 A) Pentosidine standard injected under identical conditions as B) Biological sample of an eight and one-half year old Lilac roller. C)

Biological sample of a three year-old Red siskin D) Biological sample of three year-old Red siskin spiked with a known concentration of pentosidine. 

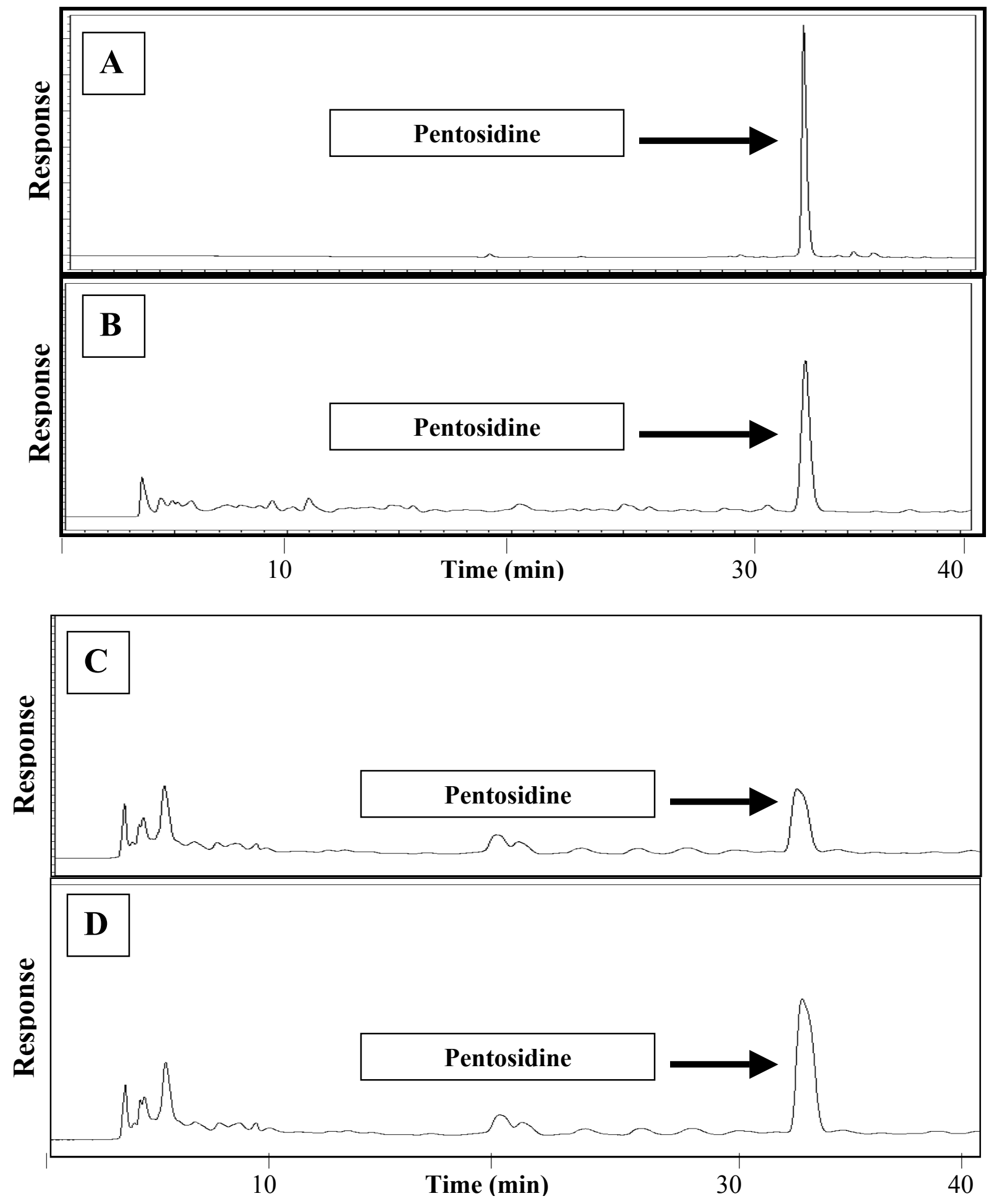
Figure 2 Pentosidine concentration in the breast skin of wild birds as a function of chronological age. 


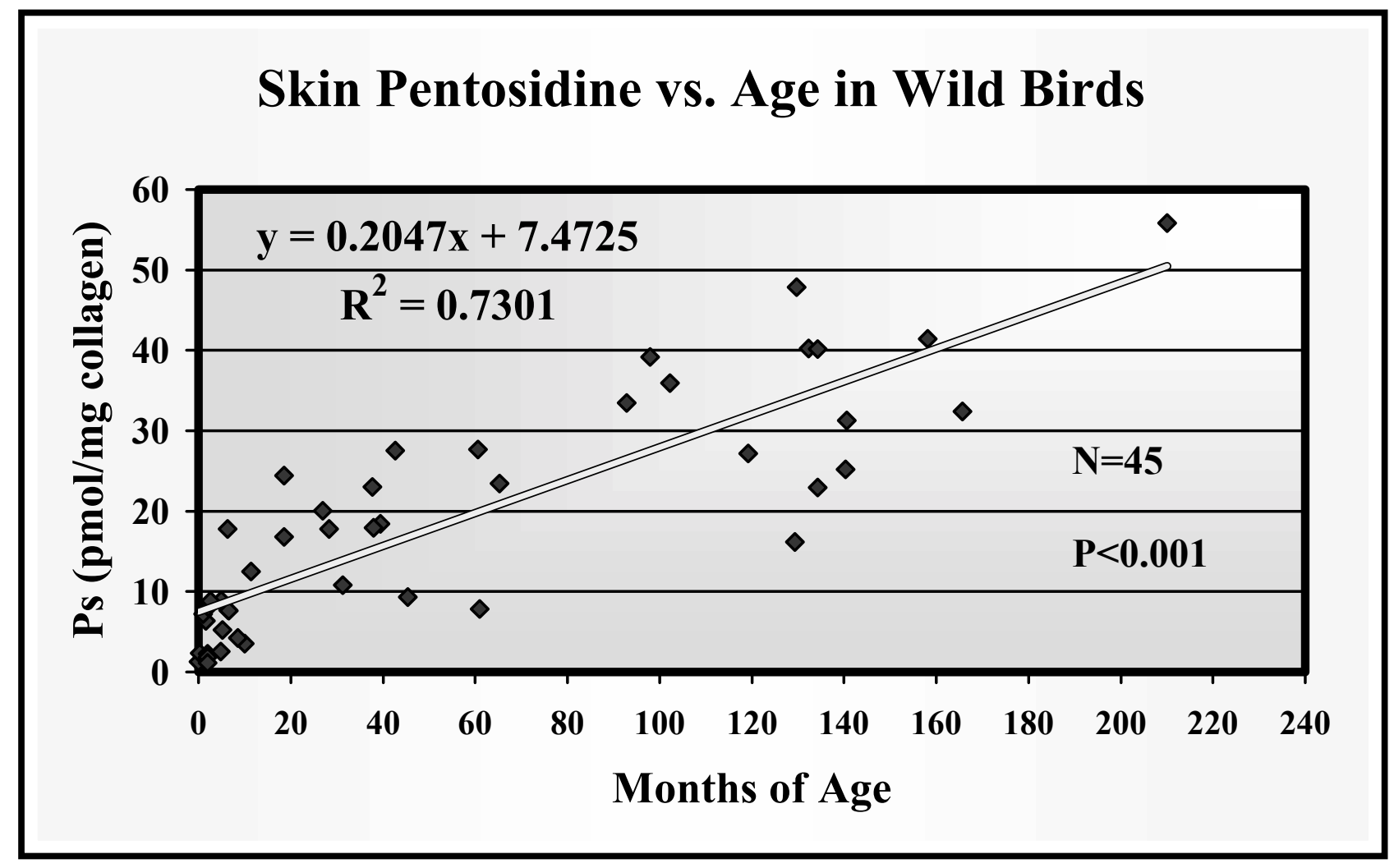


Figure 3 Pentosidine concentration in the foot webbing as a function of age in California gulls. 


\section{Foot webbing pentosidine vs. Age in gulls}

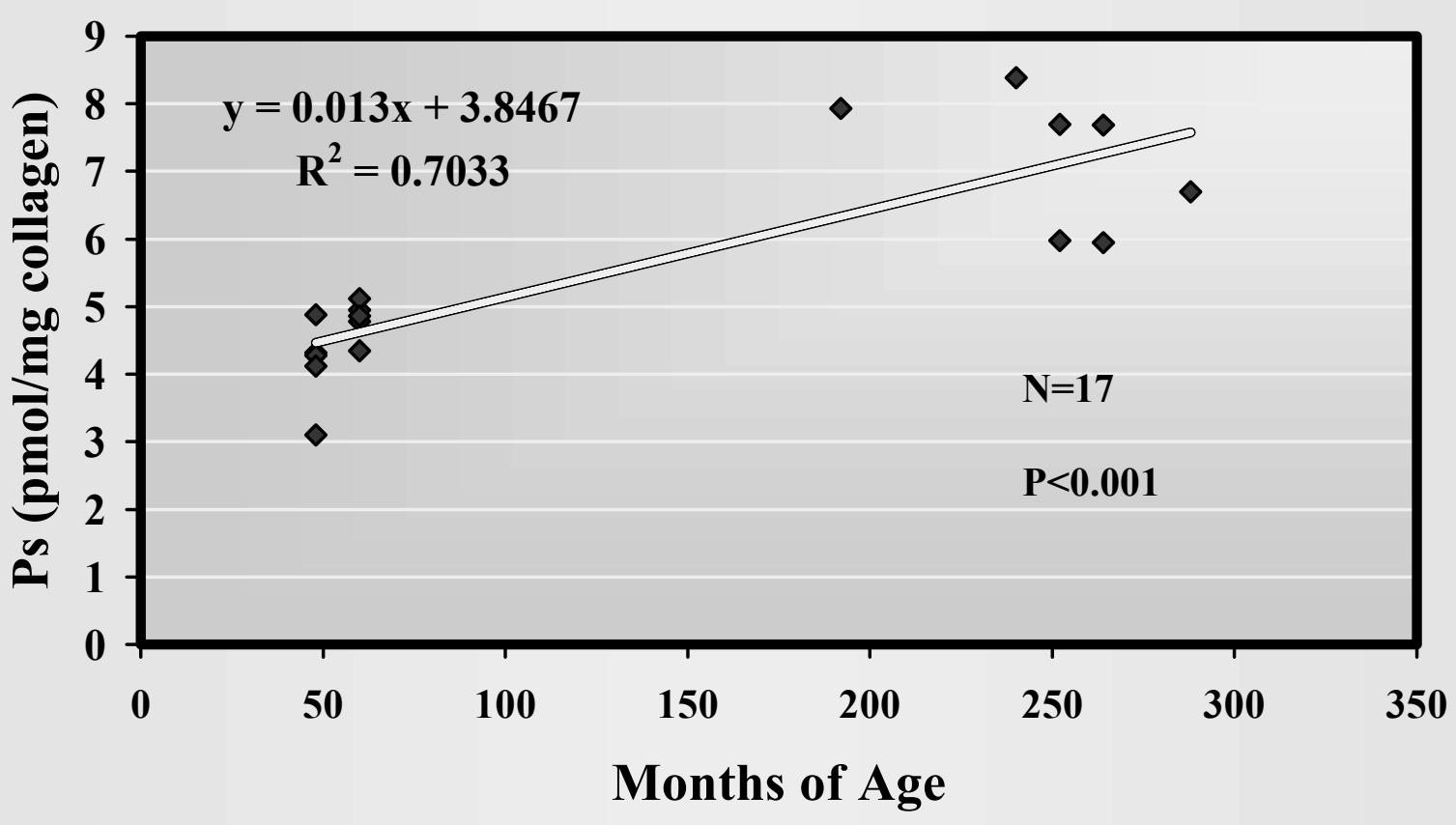


Table 1 Estimation of age for birds of unknown ages using pentosidine concentration data compiled from birds of known ages. 


\begin{tabular}{|l|l|l|}
\hline $\begin{array}{l}\text { Common } \\
\text { Name }\end{array}$ & $\begin{array}{c}\text { Pentosidine } \\
\text { pm/mg collagen }\end{array}$ & $\begin{array}{l}\text { Age in } \\
\text { Months }\end{array}$ \\
\hline Rock Dove & 14.96 & 36.58 \\
\hline $\begin{array}{l}\text { Ring-Necked } \\
\text { Pheasant }\end{array}$ & 25.68 & 88.95 \\
\hline $\begin{array}{l}\text { Racing Pigeon } \\
\text { Golden-Hooded } \\
\text { Tanager }\end{array}$ & 27.13 & 96.03 \\
\hline $\begin{array}{l}\text { Boat-Billed } \\
\text { Heron }\end{array}$ & 28.72 & 103.80 \\
\hline
\end{tabular}


Table 2 Mean collagen and pentosidine concentrations in breast skin vs. foot webbing. No significant differences between means with two-tailed t-test. 


\begin{tabular}{|l|c|c|}
\hline Sample & mg/collagen/40mg tissue & pmol Ps/mg collagen \\
\hline Breast skin & $5.73 \pm 3.04$ & $18.90 \pm 13.70$ \\
\hline Foot webbing & $3.63 \pm .963$ & $5.72 \pm 1.88$ \\
\hline
\end{tabular}


Table 3 List of all California Gull samples. Table includes areas from HPLC analysis, pentosidine concentration and age 


\begin{tabular}{|c|c|c|c|c|c|c|c|c|}
\hline \multicolumn{9}{|c|}{ GULL SAMPLES 2/28-3/2 (2000) } \\
\hline Sample \# & Avg Area & $\begin{array}{l}\text { Avg Area/ul } \\
\text { injected }\end{array}$ & $\begin{array}{l}\text { \#ul=1mg } \\
\text { Collagen }\end{array}$ & $\begin{array}{l}\text { Total Area }=1 \mathrm{mg} \\
\text { Collagen }\end{array}$ & a (standards) & b (standards) & $\begin{array}{l}\text { Ps=pmol/mg } \\
\text { collagen }\end{array}$ & Age(Months) \\
\hline AM & 1649127 & 25767.61 & 54.052 & 1392790.822 & 283628 & 11561 & 4.95 & 60.00 \\
\hline$B$ & 1152820 & 18012.81 & 76.841 & 1384122.525 & 283628 & 11561 & 4.92 & $276+$ \\
\hline C & 1329198 & 20768.72 & 58.506 & 1215094.659 & 283628 & 11561 & 4.32 & 48.00 \\
\hline $\mathrm{D}$ & 1085915 & 16967.42 & 80.917 & 1372952.876 & 283628 & 11561 & 4.88 & 48.00 \\
\hline $\mathrm{F}$ & 976168 & 15252.63 & 76.699 & 1169861.085 & 283628 & 11561 & 4.17 & unk \\
\hline G & 1593102 & 24892.22 & 67.343 & 1676316.687 & 283628 & 11561 & 5.95 & 264.00 \\
\hline $\mathrm{H}$ & 1955675 & 30557.42 & 71.021 & 2170218.659 & 283628 & 11561 & 7.69 & 264.00 \\
\hline I & 1306344 & 20411.63 & 82.558 & 1685142.937 & 283628 & 11561 & 5.98 & 252.00 \\
\hline$J$ & 1664274 & 26004.28 & 86.022 & 2236940.282 & 283628 & 11561 & 7.93 & 192.00 \\
\hline $\mathrm{K}$ & 1173329 & 18333.27 & 78.538 & 1439858.016 & 283628 & 11561 & 5.12 & 60.00 \\
\hline $\bar{M}$ & 1765428 & 27584.81 & 83.459 & 2302200.866 & 283628 & 11561 & 8.16 & unk \\
\hline $\mathrm{N}$ & 1351115 & 21111.17 & 64.697 & 1365829.487 & 283628 & 11561 & 4.86 & 60.00 \\
\hline $\mathrm{O}$ & 1422187 & 22221.67 & 54.159 & 1203503.527 & 283628 & 11561 & 4.28 & 48.00 \\
\hline$P$ & 1387682 & 21682.53 & 126.916 & 2751860.136 & 283628 & 11561 & 9.74 & $264+$ \\
\hline $\mathrm{Q}$ & 1477833 & 23091.14 & 37.524 & 866471.9608 & 283628 & 11561 & 3.10 & 48.00 \\
\hline$R$ & 637630 & 9962.97 & 100.444 & 1000720.433 & 283628 & 11561 & 3.57 & unk \\
\hline$S$ & 758897 & 11857.77 & 62.515 & 741288.218 & 283628 & 11561 & 2.65 & unk \\
\hline $\mathrm{T}$ & 1584805 & 24762.58 & 95.636 & 2368193.922 & 283628 & 11561 & 8.39 & 240.00 \\
\hline$U$ & 1619659 & 25307.17 & 74.629 & 1888648.93 & 283628 & 11561 & 6.70 & 288.00 \\
\hline $\mathrm{V}$ & 2479856 & 38747.75 & 56.058 & 2172121.37 & 283628 & 11561 & 7.70 & 252.00 \\
\hline W & 1390374 & 21724.59 & 53.301 & 1157942.571 & 283628 & 11561 & 4.12 & 48.00 \\
\hline $\mathrm{X}$ & 2093971 & 32718.30 & 58.838 & 1925079.152 & 283628 & 11561 & 6.83 & unk \\
\hline
\end{tabular}


Table 4 List of all wild bird samples including diet, Bw, genus, species and HPLC areas with pentosidine concentration and age. 


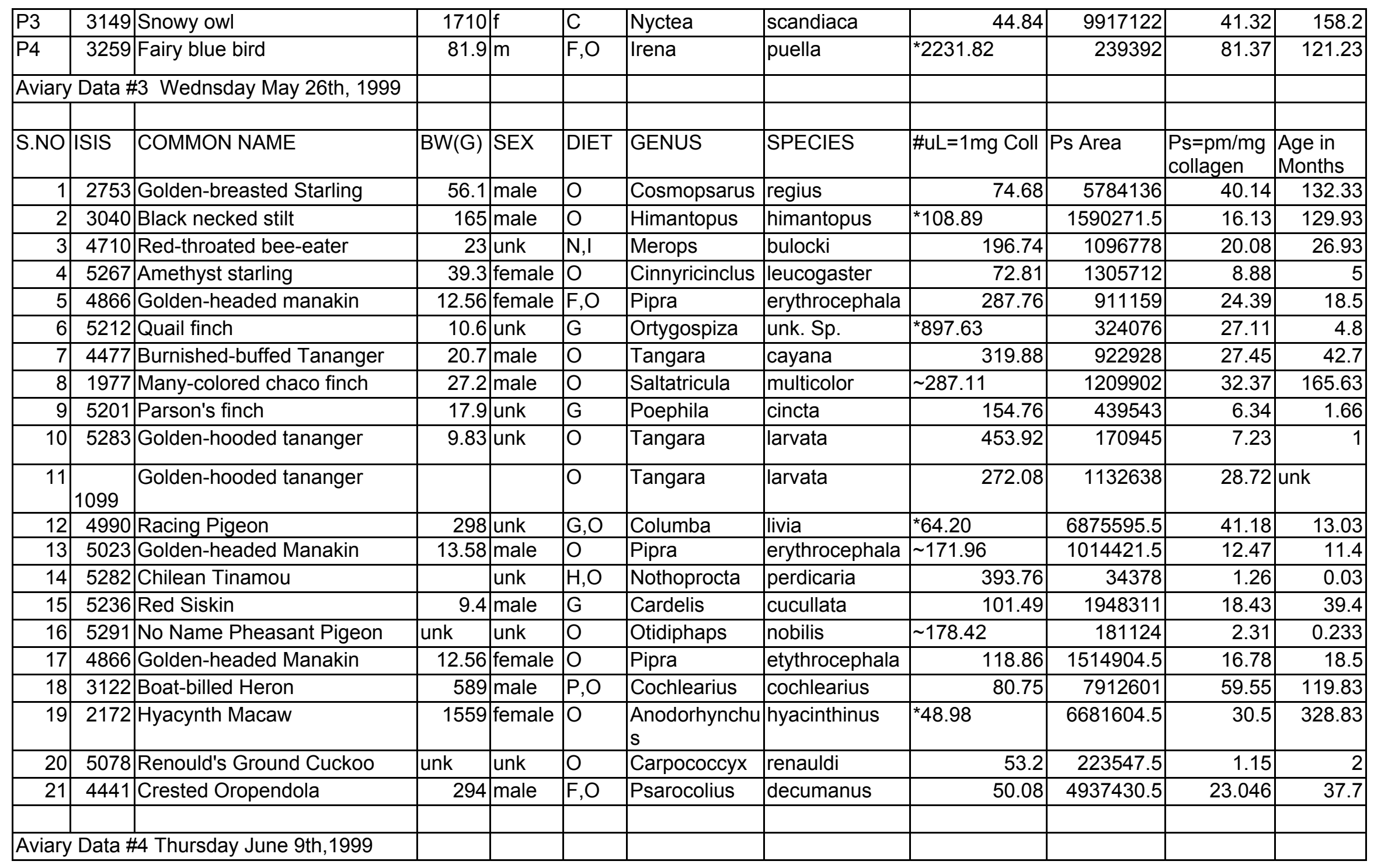




\begin{tabular}{|c|c|c|c|c|c|c|c|c|c|c|c|}
\hline \begin{tabular}{|l|l} 
S.NO & \\
\end{tabular} & ISIS & COMMON NAME & $B W(g)$ & SEX & DIET & GENUS & SPECIES & & & & \\
\hline 22 & 150 & $\begin{array}{l}\text { Ring necked pheasant invalid } \\
\text { number }\end{array}$ & & & $\mathrm{G}, \mathrm{O}$ & Phasianus & colchicus & 59.66 & 4618416 & 25.68 & unk \\
\hline 23 & 3773 & $\begin{array}{l}\text { Common beafowl Wompoo } \\
\text { Fruit Dove }\end{array}$ & 187 & male & $\mathrm{F}, \mathrm{O}$ & Ptilinopus & magnificus & 75.85 & 5544829 & 39.2 & 97.96 \\
\hline 25 & 122 & Red and white craker & 42 & male & $\mathrm{O}$ & Laterallus & leucopyrrhus & $\sim 83.64$ & 9344294 & 55.87 & 210.03 \\
\hline 26 & 5135 & Chilean tinamou & 273 & unk & $\mathrm{H}, \mathrm{O}$ & Nothoprocta & perdicaria & 96.88 & 207623 & 1.87 & 2.03 \\
\hline 27 & 4121 & Elegant crested tinamou & 605 & male & $\mathrm{H}, \mathrm{O}$ & Eudromia & elegans & 78.78 & 1274271 & 9.35 & 45.36 \\
\hline 30 & 4766 & Goldie's lorikeet & 53 & female & $\mathrm{F}, \mathrm{N}, \mathrm{O}$ & Trichoglossus & goldiei & 61.82 & 1869296.5 & 10.77 & 31.26 \\
\hline 31 & 4190 & Blue-crowned hanging parrot & 28.85 & male & $\mathrm{F}, \mathrm{N}, \mathrm{O}$ & Loriculus & galgulus & *129.69 & 7235957 & 87.46 & 52.66 \\
\hline 32 & 4594 & Black-necked stilt & 147 & male & $\mathrm{O}$ & Himantopus & himantopus & * $\sim 97.9$ & 857778.5 & 6 & 30.7 \\
\hline 33 & 4737 & American avocet & 289 & & $\mathrm{O}$ & Recurvirostra & americana & 102.13 & 372876.5 & 3.54 & 10.03 \\
\hline 34 & 4498 & White-crested Turaco & 163 & female & $\mathrm{F}, \mathrm{O}$ & Tauraco & leucolophus & 88.27 & 2178529.5 & 17.92 & 38 \\
\hline 50 & $6 m$ & Racing pigeon(1yr) & 429 & unk & $\mathrm{G}, \mathrm{O}$ & Columba & livia & 91.88 & 898679 & 7.69 & 6.466 \\
\hline 51 & 4158 & Palm Tanager & 38 & female & 0 & Thraupis & palmarum & $\sim 141.2$ & 2742471 & 27.68 & 60.53 \\
\hline 52 & 5060 & $\begin{array}{l}\text { Crested orapendola Crested } \\
\text { Oropendola }\end{array}$ & 272 & unk & $\mathrm{F}, \mathrm{O}$ & Psarocolius & decumanus & 89.1 & 967913.5 & 8.03 & 2.066 \\
\hline 53 & 3325 & Speckled mousebird & 39 & male & $F, O$ & Colius & striatus & $\sim 66.49$ & 5718714 & 27.18 & 119.23 \\
\hline 54 & 3129 & Lilac-brested Roller & 108.5 & male & $\mathrm{O}$ & Coracias & caudata & 69.12 & 8700923 & 56.05 & 121.46 \\
\hline 55 & 3644 & Lilac brested roller & 91 & female & $\mathrm{O}$ & Coracias & caudata & 63.83 & 6042586 & 35.94 & 102.26 \\
\hline 56 & 4890 & Black crake(5mnths) & 54.2 & male & 0 & Limnocorax & flavirostra & 78.45 & 349429 & 2.55 & 4.766 \\
\hline 57 & 5959 & Racing Pigeon & 287 & unk & $G, O$ & Columba & livia & $\sim 69.86$ & 5432095 & 27.13 & unk \\
\hline 58 & 3288 & Blue-crowned Motmot & 120 & female & $\mathrm{O}$ & Momotus & momota & $\sim 95.19$ & 4591676 & 31.24 & 140.6 \\
\hline 59 & 4336 & $\begin{array}{l}\text { Great Egret(skin from } \\
\text { leg)9yrs. }\end{array}$ & 948 & unk & $\begin{array}{l}P, C= \\
O\end{array}$ & Egretta & alba & $\star \sim 144.76$ & 12877908.5 & 133.27 & 108 \\
\hline
\end{tabular}




\begin{tabular}{|c|c|c|c|c|c|c|c|c|c|c|c|}
\hline 60 & 16 & Snowy Egret(very old) & 418 & unk & $\begin{array}{l}P, C= \\
O\end{array}$ & Egretta & thula & $\sim 55.939$ & 21702263 & 86.73 & unk \\
\hline 61 & 4928 & Great blue heron & 1800 & unk & $\begin{array}{l}P, C= \\
O\end{array}$ & Ardea & herodias & $\sim 53.15$ & 2329516.5 & 8.85 & 2.6 \\
\hline \multicolumn{12}{|c|}{$\begin{array}{l}\text { Aviary Data \# } 6 \text { Thursday, August 5th, } \\
1999\end{array}$} \\
\hline S.NO & ISIS & COMMON NAME & $B W(g)$ & SEX & DIET & GENUS & SPECIES & & & & \\
\hline 62 & 4904 & $\begin{array}{l}\text { Nompoo fruit dove Wompoo } \\
\text { Fruit Dove }\end{array}$ & 200 & male & $\mathrm{F}, \mathrm{O}$ & Ptilinopus & Magnificus & *81.8 & 5110887.5 & 38.96 & 10.53 \\
\hline 63 & 3062 & $\begin{array}{l}\text { Schalout's turaco Schalow's } \\
\text { Turaco }\end{array}$ & 187 & male & $\mathrm{F}, \mathrm{O}$ & Tauraco & corythaix & $\sim 54.26$ & 8624424.5 & 33.45 & 92.9 \\
\hline 64 & 5039 & $\begin{array}{l}\text { Sooty headed bulhi Sooty- } \\
\text { headed Bulbul }\end{array}$ & 32 & male & 0 & Pycnonotus & aurigaster & $\sim 135.25$ & 810330.5 & 7.83 & 60.93 \\
\hline 65 & 1969 & Nicobar Pigeon & 545 & male & $\begin{array}{l}F, G= \\
O\end{array}$ & Caloenas & nicobarica & $\sim 71.97$ & 4902347 & 25.22 & 140.3 \\
\hline 66 & 5173 & African pygmy goose & 170 & female & $\mathrm{O}$ & Nettapus & auritus & 96.89 & 466715.5 & 4.21 & 8.56 \\
\hline \multicolumn{3}{|c|}{$\begin{array}{l}\text { Aviary Data \# } 7 \text { Thursday, October 21st, } \\
1999\end{array}$} & $\mathrm{BW}(\mathrm{g})$ & SEX & DIET & GENUS & SPECIES & & & & \\
\hline S.NO & ISIS & COMMON NAME & & & & & & & & & \\
\hline 67 & 5312 & Chilean Tinamou & 476 & unk & $\mathrm{H}, \mathrm{O}$ & Nothoprocta & perdicaria & $\sim 67.19$ & 1587057.5 & 7.62 & 6.53 \\
\hline 68 & 4912 & Southern White-bellied Caique & 161.3 & Male & $\mathrm{O}$ & Pionites & leucogaster & $\sim 44.97$ & 5537349 & 17.8 & 28.36 \\
\hline 69 & 3233 & Fire-tufted Barbet & 110 & female & $\mathrm{O}$ & Psilopogon & pyrolophus & 37.61 & 13658776.5 & 47.88 & 129.7 \\
\hline 70 & 5000 & Racing Pigeon & 354 & unk & $\mathrm{G}, \mathrm{O}$ & Columba & livia & $* \sim 43.69$ & 9398202 & 29.35 & 18.36 \\
\hline 71 & & $\begin{array}{l}\text { Rock Dove(Red leg band)No } \\
\text { ID }\end{array}$ & unk & unk & $\mathrm{G}, \mathrm{O}$ & Columba & livia & 119.75 & 1341167 & 14.96 & unk \\
\hline 72 & 4765 & $\begin{array}{l}\text { Golden Lorikeet Goldie's } \\
\text { Lorikeet }\end{array}$ & 45 & female & $\begin{array}{l}\mathrm{F}, \mathrm{N}= \\
\mathrm{O}\end{array}$ & Trichoglossus & goldiei & 48.84 & 2081530 & 17.76 & 6.33 \\
\hline 73 & 5264 & Pheasant Pigeon & 416 & female & 0 & Otidiphaps & nobilis & $\sim 44.59$ & 1214680 & 3.87 & 96.83 \\
\hline 74 & 4394 & Pheasant Pigeon & 469 & female & 0 & Otidiphaps & nobilis & 71.7 & 3507042 & 23.44 & 65.3 \\
\hline 75 & 3321 & Hooded Pitta & 45 & female & 0 & Pitta & sordida & 153.46 & 2807266 & 40.15 & 134.3 \\
\hline
\end{tabular}


Figure 4. Pentosidine standard curve used to calculate pentosidine concentrations in the foot webbing of California Gulls. 


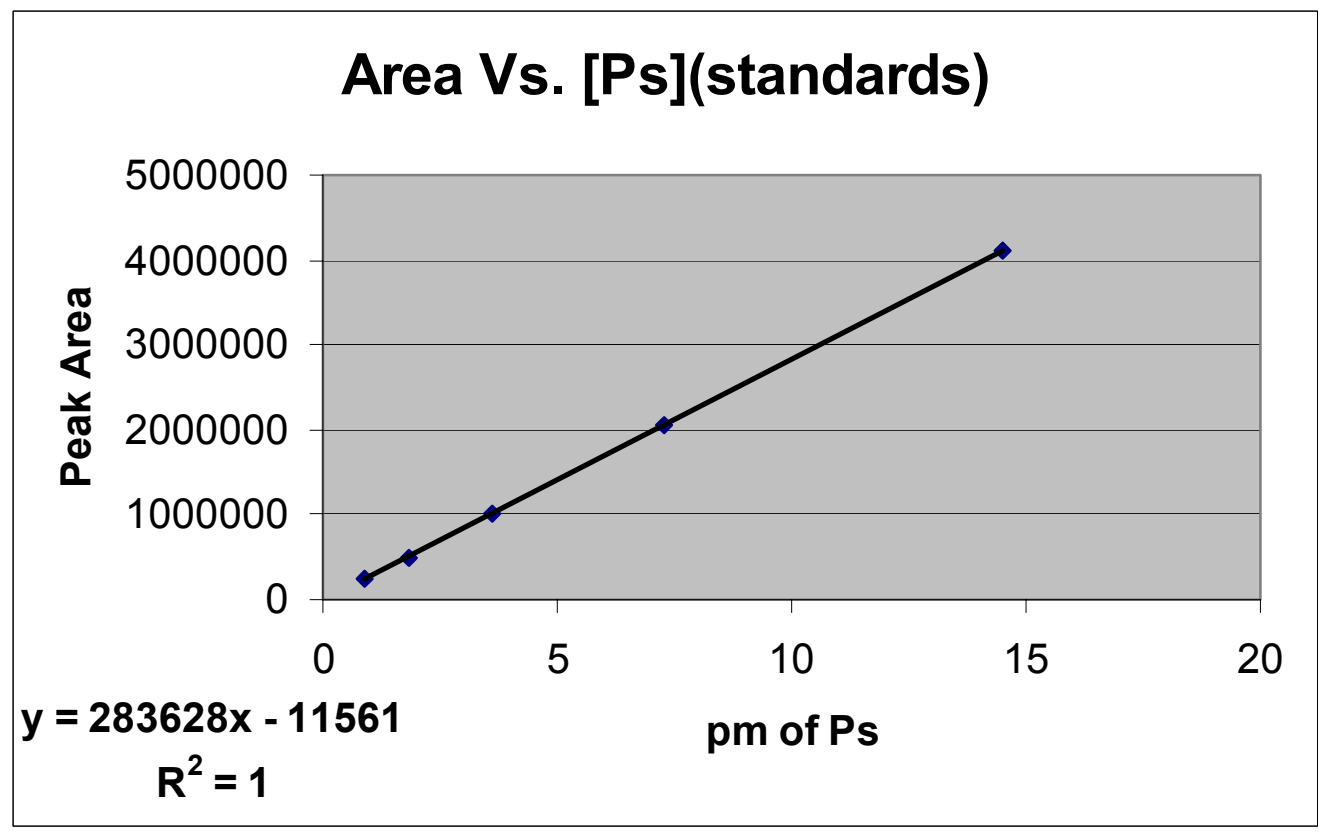

\section{Standards}

pmol Ps Avg Area

$14.5 \quad 4099808$

$7.25 \quad 2048371$

$3.625 \quad 1014487$

$1.8125 \quad 501895$

0.90625245800 


\section{Bibliography}

Austad, S., and Fischer, K. 1991. Mammalian aging, metabolism, and ecology: evidence from bats and marsupials. J. Gerontol: Biol. Sci. 46:B47B53.

Barja, G., Cadenas, S., Rojas, C., Perez-Campo, R.., Lopez-Torres, R. 1994. Low mitochondrial free radical production per unit $\mathrm{O}_{2}$ consumption can explain the simultaneous presence of high longevity and high aerobic metabolic rate in birds. Free. Rad. Res. 21:317-328.

Baynes, J.W., and Monnier, V.M. 1989. eds. The Maillard reaction in aging, diabetes, and nutrition. In: Progress in clinical biology research. New York, Alan R. Liss.

Baynes, J.W. 1991. Role of oxidative stress on development to complications in diabetes. Diabetes 40:405-412.

Bellmunt, M.J., Portero M., Pamplona, R., Cosso, L., Odetti P., and Prat J., 1995. Evidence for the Maillard reaction in rat lung collagen and its relationship with solubility and age. Biochimica et Biophysica Acta. 1272:53-60.

Beuchat, C.A., and Chong, C.R. 1998. Hyperglycemia and its consequences for hemoglobin glycation. Comp. Biochem. Physiol. A120:409-416

Cerami, A. 1985. Hypothesis: Glucose as a mediator of aging. J. Am. Geriatr. Soc. 33:626-634.

Cerami, A., Vlassara, J., and Brownlee, M., 1987. Glucose and aging. Science 256: 90-96.

Chellan, P., and Nagaraj, R.H. 1999. Protein crosslinking by the Maillard reaction: dicarbonyl-derived imidazoliam crosslinks in aging and diabetes. Arch. Biochem. Biophys. 368:98-104.

Comfort, A., 1979. The biology of senescence, $3^{\text {rd }}$ ed. New York: Elsevier. 
Dyer, D.G., Blackledge, J.A., Thorpe, S.R., and Baynes, J.W. 1991a. Formation of pentosidine during nonenzymatic browning of proteins by glucose. J. Biol. Chem. 266:11554-11560.

Dyer, D.G., Blackledge, J.A., Thorpe, S.R., Baynes, J.W. 1991b. Formation of pentosidine during nonenzymatic browning of proteins by glucose: identification of glucose and other carbohydrates as possible precursors of pentosidine in vivo. J. Biol. Chem. 266:11654-11660.

Edney E.B., Gill R.W. 1968. Evolution of senescence and specific longevity. Nature 220(164):281-282.

Finch, C.E., 1990. Longevity, senescence, and the genome. University of Chicago Press.

Grandhee, S.K., and Monnier, V.M. 1991. Mechanism of formation of the Maillard protein cross-link pentosidine. Glucose, fructose, and ascorbate as pentosidine precursors. J. Biol. Chem. 266:11649-11653.

Herrero, A., and Barja, G. 1988. $\mathrm{H}_{2} \mathrm{O}_{2}$ production of heart mitochondria and aging rate are slower in canaries and parakeets than in mice: sites of free radical generation and mechanisms involved. Mech. Ageing. Dev. 103:133146.

Holiday, R. 1992. The ancient origins and causes of aging. News Physiol. Sci. 7:34-40.

Holmes, J. D., and Austad, S. N. 1995. Birds as animal models for the comparative biology: prospectus. J. Geront: Biol. Sci. 50A:B59-B66.

Holmes, J.D., Fluckiger, R., and Austed, S.N. 2001. Comparative biology of aging in birds: an update. Exp. Gerontol. In Press.

Iqbal, M., Probert, L.L., and Klandorf, H. 1997. Effect of dietary aminoguanidine on tissue pentosidine and reproductive performance in broiler breeder hens. Poultry Sci. 76:1574-1579.

Iqbal, M., Probert, L.L., Al-humadi, N.H. and Klandorf, H. 1999. Protein glycosylation and advanced glycosylation endproducts (AGEs): An avian solution. J. Gerontol: Biol. Sci. 54: B1-B6. 
Iqbal, M., Kenney, P.B., Klandorf, H. 1999. Age-related changes in meat tenderness and tissue pentosidine: Effect of diet restriction and aminoguanidine in broiler breeder hens. Poultry Sci. 78:1328-1333.

Johnson, B.F., Sinclair, D.A., and Guarente, L. 1999. Molecular biology of aging. Cell 96:291-302.

Klandorf, H., Probert, L.L., and Iqbal, M. 1999. In the defense against hyperglycemia: An avian strategy. World Poultry Sci. 55:1-17.

Kristal, B.A. amd Yu, B. P. 1992. An emerging hypothesis: synergistic induction of aging by free radicals and Maillard reactions. J. Gerontol. Biol. Sci. 47:B107-114.

Ku, H.H., and Sohal, R.S. 1993. Comparison of mitochondrial pro-oxidant generation and anti-oxidant defenses between rat and pigeon: possible basis of variation in longevity and metabolic potential. Mech. Ageing. Dev. 72:6776.

Lindstedt, S. L., and Calder, W. A. 1976. Body size and longevity in birds. Condor 78:91-94.

Masaro, E.J., Katz, M.S., McMahan, C.A. 1989. Evidence for the glycation hypothesis of aging from the food restricted rodent model. J.Gerontol. 44:B20-22.

McCormick, R.J. 1999. Extracellular modifications to muscle collagen: implications for meat quality. Poultry Sci. 78:785-791.

Monnier, V.M., Vishwanath, V., Frank, K.E., Elmets, C.A., Dauchot, P., and Kohn, P.R. 1986. Relationship between complications of type I diabetes mellitus and collagen-linked fluorescence. N. Engl. J. Med. 314:403-408.

Monnier, V.M., 1990. Nonenzymatic glycosylation, the Maillard reaction and the aging process. J. Gerontol. Biol. Sci. 45:B105-B111.

Monnier, V.M., Sell, D.R., Nagaraj, RH. Mityata, S. 1991. Mechanisms of protection against damage mediated by the Maillard reaction in aging. Gerontology 37:152-165. 
Nagaraj, R.H., Timothy, T.S., Sell, D.R., Fogarty, J., Engerman, R.L., and Monnier, V.M. 1996. Evidence of a glycemic threshold for the formation of pentosidine in diabetic dog lens but not in collagen. Diabetes 45:587-594.

Nelson, J.F., Karelus, K., Bergman, M.D., and Felicio, L. S. 1995. Neuroendocrine involvement in aging - evidence from studies of reproductive aging and caloric restriction. Neurobiol. Aging 16:837-843.

Ogburn, C.E., Austed, S.N., Holmes, D.J., Kiklevich, J.V., Gollahon, K., Rabinovich, P.S., and Martin, G.M. 1998. Cultured renal epithelial cells from birds and mice: enhanced resistance of avian cells to oxidative stress and DNA damage. J. Gerontol. Biol. Sci. 53A:B287-B289.

Polharna, H.K., Monnier, V.M., Boja, B., and Moskowitz R. W. 1995. Lysyl oxidase and Maillard reaction-mediated crosslinks in aging and osteoarthritic rabbit cartilage. J. Orthopedic Res. 13:13-21.

Reiser, K.M. 1994. Influence of age and long-term dietary restriction on enzymatically mediated crosslinks and nonenzymatic glycation of collagen in mice. J. Gerontol: Biol. Sci. 49:B71-B79.

Reiser, K.M. 1991. Nonenzymatic glycation of collagen in aging and diabetes. Proc. Soc. Exp. Biol. Med. 196:17-29

Reiser, K.M., McCormick, R.J., Rucker, R. 1992. Enzymatic and nonenzymatic cross-linking of collagen and elastin. FABES. 6:2439-2449.

Reiser, K.M.,McGee C., Rucker R., and McDonald R. 1995. Effects of aging and caloric restriction on extracellular matrix biosynthesis in a model of injury repair in rats: J. Geron. Biol. Sci. 50A:B40-B47.

Ricklefs, R.E. 1998. Evolutionary theories of aging: conformation of a fundamental prediction, with implications for the genetic basis and evolution of life span. Amer. Nat. 152:22-24.

Ross, M.H., Romrell, L.J., Kaye, G. 1995. Histology: a text an atlas. Williams and Wilkins. Batimore, MD.

Siegel, R.C. 1979. Lysyl oxidase. Int. Rev. Connect.Tissue Res. 8:73-118. 
Sell, D.R., and Monnier, V.M. 1989a. Isolation, purification, and partial characterization of novel flurophores from aging human insoluble collagenrich tissue. Conn.Tiss.Res. 19:77-92.

Sell, D.R., and Monnier, V.M. 1989b. Structure elucidation of a senescence cross-link from human extracellular matrix. Implication of pentoses in the aging process. J.Biol.Chem. 264:21597-21602.

Sell, D.R., Lapolla, A., Odetti, P., Fogarty, J,. and Monnier, V.M. 1992. Pentosidine formation in skin correlates with severity of complications in individuals with long-standing IDDM. Diabetes 41:1286-1291.

Sohal, R.S. and Weindruch, R. 1996. Oxidative stress, caloric restriction, and aging. Science 273: 59-63.

Van Remmen, H., Ward, W.F., Sabia, R.V., and Richardson, A. 1995. Gene expression and protein degradation. In: Handbook of Physiology (Masaro, E. J., ed.) pp.171-234. Oxford University Press, New York, NY.

Verzijl., N., Degroot, J., Thorpe, S.R., Bank, R.A., Shaw J.N., Lyons, T.J., Bijlsma, J.W.J., Lafeber, F.P.J., Baynes, J.W., and TeKoppele, J.M. 2000. Effect of collagen turnover on the accumulation of advanced glycation end products. J. Biol. Chem. 275:39027-39031.

Walford, R.L., and Spindler, S.R. 1997. The response to caloric restriction in mammals shows features also common to hibernation: a cross-adaptation hypothesis. J. Gerontol. Bio. Sci. 52:B179-B183.

Weindruch, R. and Walford, R.L. 1982. Dietary restriction of mice beginning at one year of age: Effect of life span and spontaneous cancer incidence. Science 215:1415-1418.

Weindruch, R. and Walford, R.L. 1988. The retardation of aging and disease by dietary restriction. Springfield, IL Charles C. Thomas.

Weindruch, R., Kayo, T., Lee, C., and Prolla T.A. 2001 Microarray profiling of gene expression in aging and its alterations by caloric restriction in mice. J. Nutr. 131:918S-926S. 
Wells-Knecht, K. J., Brinkmann, E., Wells-Knecht, M.C., Litchfield, J.E., Ahmed, M.U., Reddy, S., Zyzak, D.V., Thorpe, S.R., and Baynes, J.W. 1996 New biomarkers of Maillard reaction damage to proteins. Nephrol. Dial. Transplant. 11supp5:41-47 . 